\title{
The genetic effects of the dopamine D1 receptor gene on chicken egg production and broodiness traits
}

\author{
Haiping $\mathrm{Xu}^{1 \dagger}, \mathrm{Xu}$ Shen ${ }^{1 \dagger}$, Min Zhou $^{1,2}$, Meixia Fang ${ }^{1,3}$, Hua Zeng ${ }^{1}$, Qinghua Nie ${ }^{1}$, Xiquan Zhang ${ }^{1 *}$
}

\begin{abstract}
Background: The elevation of egg production and the inhibition of incubation behavior are the aims of modern poultry production. Prolactin (PRL) gene is confirmed to be critical for the onset and maintenance of these reproductive behaviors in birds. Through PRL, dopamine D1 receptor (DRD1) was also involved in the regulation of chicken reproductive behavior. However, the genetic effects of this gene on chicken egg production and broodiness have not been studied extensively. The objective of this research was to evaluate the genetic effects of the DRD1 gene on chicken egg production and broodiness traits.

Results: In this study, the chicken DRD1 gene was screened for the polymorphisms by cloning and sequencing and 29 variations were identified in 3,342 bp length of this gene. Seven single nucleotide polymorphism (SNPs) among these variations, including a non-synonymous mutation (A+505G, Ser169Gly), were located in the coding region and were chosen to analyze their association with chicken egg production and broodiness traits in 644 Ningdu Sanhuang individuals. Two SNPs, G+123A and C+1107T, were significantly associated with chicken broody frequency $(P<0.05)$. Significant association was also found between the $G+1065 \mathrm{~A}-\mathrm{C}+1107 \mathrm{~T}$ haplotypes and chicken broody frequency $(P<0.05)$. In addition, the haplotypes of $\mathrm{G}+123 \mathrm{~A}$ and $\mathrm{T}+198 \mathrm{C}$ were significantly associated with weight of first egg (EW) $(P=0.03)$. On the other hand, the distribution of the DRD1 mRNA was observed and the expression difference was compared between broodiness and non-broodiness chickens. The DRD1 mRNA was predominantly expressed in subcutaneous fat and abdominal fat of non-broodiness chicken, and then in heart, kidney, oviduct, glandular stomach, hypothalamus, and pituitary. In subcutaneous fat and abdominal fat, the level of non-broodiness was 26 to 28 times higher than that of broodiness. In pituitary, it was 5-fold higher. In heart, oviduct, and kidney, a 2-3 times decrease from non-broodiness to broodiness was displayed. In glandular stomach and hypothalamus, the level seen in non-broodiness and broodiness was almost the same.
\end{abstract}

Conclusion: The polymorphisms of the DRD1 gene and their haplotypes were associated with chicken broody frequency and some egg production traits. The mRNA distribution was significant different between broodiness and non-broodiness chickens.

\section{Background}

In modern poultry production, chickens are constantly selected for a high rate and persistency of egg laying. However, incubation behavior usually results in the regression of ovary and the cessation of egg laying [1,2]. In addition, following the adoption of artificial

\footnotetext{
* Correspondence: xqzhang@scau.edu.cn

† Contributed equally

'Department of Animal Genetics, Breeding and Reproduction, College of Animal Science, South China Agricultural University, Guangzhou 510642, Guangdong, China
}

(c) 2010 Xu et al; licensee BioMed Central Ltd. This is an Open Access article distributed under the terms of the Creative Commons Attribution License (http://creativecommons.org/licenses/by/2.0), which permits unrestricted use, distribution, and reproduction in any medium, provided the original work is properly cited.

incubation technology, incubation behavior is no longer required in chicken production. Therefore the inhibition or eradication of incubation behavior has received much attention as a potential target of egg production improvement. Recently with the development of molecular biological approaches, the genetic basis of broodiness has been extensively studied. It is a polygenic trait controlled by at least two dominant autosomal genes $[3,4]$. Although a study [2] to search the QTL of broodiness was carried out, to date no QTL was identified by genome-wide scan approach. On the other hand, many 
investigations about the genetic basis of egg production and broodiness have been performed through candidate gene analysis, especially for the prolactin $(P R L)$ gene [5-8]. PRL is postulated to play a critical role in the onset and maintenance of incubation behavior in birds [9-12]. Some other factors, such as dopamine, have pivotal effects on PRL secretion [13-15].

Dopamine, an abundant neurotransmitter in the central nervous system and periphery, has been shown to play important roles in cognition, emotion, endocrine function, and hyperprolactinemia in mammals [16-19]. Its physiological effects are exerted through activating dopamine receptors. So far, at least five distinct dopamine receptors subtypes, DRD1-DRD5, have been identified and classically divided into two classes referred to as D1-like (DRD1 and DRD5) and D2-like (DRD2, DRD3, and DRD4) receptors based on their pharmacological, biochemical, and physiological differences [20-22]. All of these receptors are G protein-coupled receptors with 7 transmembrane domains. In avian, dopamine was demonstrated to be involved in both stimulating and inhibiting PRL secretion in the brain [23]. Dopamine stimulates PRL secretion via activating DRD1 at the hypothalamus level by operating through vasoactive intestinal peptide (VIP) [24-26]. And the inhibition effect of dopamine on PRL secretion is mediated through DRD2 receptors at the pituitary level $[27,28]$. Hens treated with dopamine receptor antagonist or receptor blocking agent resulted in terminated maintenance of broodiness by inhibiting secretion of PRL [29-31]. Sartsoongnoen also found that an association existed between DA neurons and the regulation of the reproductive system in Thai chickens [32]. All these studies suggested that dopamine receptor was involved in the regulation of avian reproductive behavior. In this study, the DRD1 gene was chosen as a candidate gene to analyze the genetic effect on chicken egg production and broodiness traits.

Like other D1-like members, the chicken DRD1 is an intronless gene and belongs to the rhodopsin family. It is located on chromosome 13 and contains an open reading frame of 1356 nucleotides encoding a protein of 451 amino acids [33]. Demchyshyn found that chicken DRD1 mRNA was predominantly expressed in the brain and to a much less extent in the kidney, whereas in other peripheral tissues such as, spleen, liver, heart and lung, no expression was detected by Northern blot analysis [34]. Recently, some studies demonstrated that the $D R D 1$ gene was widely expressed in the hypothalamus and pituitary and the expression was correlated with the reproductive system in turkeys [35,36]. Schnell indicated that no significant difference was observed in hypothalamic expression of the DRD1 gene throughout the reproductive cycle, as well as in pituitary [35]. However, subsequent investigation showed that the hypothalamic expression increased in hyperprolactinemic incubating turkey hens [36].

Although the mRNA expression patterns of the DRD1 gene were partially reported in avian, the associations of these patterns and the $D R D 1$ gene polymorphisms with chicken reproductive traits remained unclear. The aim of the present research was to screen polymorphisms in the DRD1 gene coding region and evaluate their genetic effects on chicken egg production and broodiness traits. Furthermore, the mRNA expression difference of this gene was investigated between broody and non-broody chickens.

\section{Methods}

\section{Chicken Populations}

A total of 24 unrelated chickens were used to identify the mutations in the DRD1 gene. They were from 6 populations (4 from each) including Red Jungle Fowls (RJF), Taihe Silkies (TS), Xinghua chickens (XH), Gushi chickens (GS), White Recessive Rock Broilers (WRR), and Leghorn Layers (LH). The detail information of the populations was shown in Table 1.

The population for association study consisted of 644 female Ningdu Sanhuang (NDH) chickens obtained from Guangdong Wens Foodstuff Corporation Ltd. (Guangdong, China). These birds were randomly selected from 1477 unrelated birds. All NDH female chickens were fed with free access to water and feed to $77 \mathrm{~d}$ of age, and then changed to feed a corn-soy-beanbased diet with $15 \% \mathrm{CP}$ and 2,900 kcal of ME/ kg. All of them were exposed to a continuous $24 \mathrm{~h}$ photoperiod during the first $2 \mathrm{~d}$ of age, and then changed to and maintained under a daily light period of $16 \mathrm{~h}$. They were reared in individual laying cages after $90 \mathrm{~d}$ of age. In this population, age of first egg (AFE), total egg number from 90 to $300 \mathrm{~d}$ of age (EN), total number of qualified eggs from 90 to $300 \mathrm{~d}$ of age (QEN), total number of oafish eggs from 90 to $300 \mathrm{~d}$ of age (OEN), and weight of first egg (EW) were observed. Qualified eggs were recognized with the criteria as: clean and smooth surface, ellipse shape with a big end and a small end, hard and complete eggshell, stable equilibrium color, similar in size and shape, a good sense of heaviness in hand, crisp noise and hardly breakup after mutual collision. Oafish eggs were abnormal eggs including doubleyolk eggs, soft-shell eggs, ruptured eggs, rough-shell eggs, crack eggs, wrinkle eggs and so on.

In addition, from $90 \mathrm{~d}$ to $300 \mathrm{~d}$ of age the incubation behavior of chickens was observed and recorded at 16:00 pm everyday. The criteria for broody behaviors have been published elsewhere [8]. Briefly, when hens exhibited increased body temperature, nesting, incubating, feather loosening, lacking of luster throughout the 
Table 1 The characterization of the populations used in this study

\begin{tabular}{|c|c|c|}
\hline Populations & Origin & Production performance \\
\hline Red Jungle Fowls (RJF) & Linshan County, Guangxi, China & $\begin{array}{l}\text { Seasonal reproduction and broodiness; an egg-production of } 60 \\
\text { per year. }\end{array}$ \\
\hline $\begin{array}{l}\text { Taihe Silkies } \\
\text { (TS) }\end{array}$ & Taihe County, Jiangxi, China & $\begin{array}{l}\text { A } 70 \text { to } 80 \% \text { incidence of broodiness; an egg-production of } 70-80 \\
\text { per year. }\end{array}$ \\
\hline Xinghua chickens $(\mathrm{XH})$ & Fengkai County, Guangdong, China & $\begin{array}{l}\text { A } 70 \text { to } 80 \% \text { incidence of broodiness; an egg-production of } 60-90 \\
\text { per year. }\end{array}$ \\
\hline Gushi chickens (GS) & Gushi County, Henan, China & $\begin{array}{l}\text { A } 10 \text { to } 20 \% \text { incidence of broodiness; an egg-production of } 141 \\
\text { per year. }\end{array}$ \\
\hline $\begin{array}{l}\text { White Recessive Rock Broilers } \\
\text { (WRR) }\end{array}$ & $\begin{array}{l}\text { Commercial broiler line imported from Kabir Co } \\
\text { Ltd, Italy }\end{array}$ & No broodiness in cage; an egg-production of 180 per year. \\
\hline Leghorn Layers (LH) & Commercial layer line derived from Italy & No broodiness; an egg-production of 250-300 per year. \\
\hline $\begin{array}{l}\text { Ningdu Sanhuang chickens } \\
(\mathrm{NDH})\end{array}$ & Ningdu County, Jiangxi, China & $\begin{array}{l}\text { A } 50 \text { to } 60 \% \text { incidence of broodiness; an egg-production of } 110- \\
130 \text { per year. }\end{array}$ \\
\hline
\end{tabular}

body, specific clucking, being more defensive and aggressive, and lost their appetite, they were considered to be in broody. In the association analysis, two parameters, duration of broodiness (DB) and broody frequency (\%), were investigated. DB was estimated by the total number of days a hen being in broody during the observation period. Broody frequency (\%) was calculated by the percentage of broody chickens, and here individuals exhibiting obvious broody behavior for more than $1 \mathrm{~d}$ were identified as broody chickens considering enough sample numbers in statistics.

The distribution pattern of the DRD1 mRNA was studied in NDH female chickens. The expression differences were compared between $6 \mathrm{NDH}$ chickens in broody and 6 individuals in non-broody in various kinds of tissues (heart, liver, spleen, lung, kidney, breast muscle, leg muscle, gizzard, glandular stomach, pituitary, hypothalamus, ovary, oviduct, duodenum, subcutaneous fat, and abdominal fat). All the tissues of broody chickens were taken at the midpoint (the fourth day after the onset of broody behavior) of broodiness and those of non-broody chickens were taken at the same day. All animal experiments were conducted in accordance with Law of the People's Republic of China on Animal Protection.

\section{DNA Extraction, PCR Amplification and Polymorphismldentification}

Genomic DNA was isolated from blood using the traditional method. Two pairs of primers (P1 and P2, shown in Table 2) used for the amplification of the chicken $D R D 1$ gene were designed according to the published mRNA sequence [GenBank: NM_001144848] by Genetool software (http://www.biologysoft.com/; BioTools, Alberta, Canada). The polymorphisms of the whole $D R D 1$ coding region were identified through the amplification of a 1970-bp fragment by primer P2 (Table 2). The PCR reactions were carried out in a total volume of $25 \mu \mathrm{L}$ containing $50 \mathrm{ng}$ of genomic DNA, $1 \mu \mathrm{M}$ of each primer, $200 \mu \mathrm{M}$ dNTP, $1.5 \mathrm{mM} \mathrm{MgCl} 2,1 \times$ PCR buffer and $1 \mathrm{U}$ of Taq DNA polymerase (Sangon Biological

Table 2 Detail information for primers of the chicken DRD1 gene

\begin{tabular}{|c|c|c|c|c|c|}
\hline Primer name & $\begin{array}{l}\text { Primer sequence } \\
\left(5^{\prime} \rightarrow 3^{\prime}\right)\end{array}$ & Length $^{1}$ (bp) & Location $^{2}$ & $\mathrm{AT}^{3}\left({ }^{\circ} \mathrm{C}\right)$ & Genotyping method \\
\hline P1 & $\begin{array}{l}\text { F:CCGGTGAGTACCCTGCTIT } \\
\text { R:GTGCTTITCCTCTGCTTTGG }\end{array}$ & 1504 & $-1961 \sim-458$ & 59 & / \\
\hline P2 & $\begin{array}{l}\text { F:AGTGAAGAATTGCTCGCTGA } \\
\text { R:GGTTITGCTGGGTACACCTT }\end{array}$ & 1970 & $-589 \sim+1381$ & 57 & / \\
\hline P3 & $\begin{array}{l}\text { F:CACTATGGATGGGGAAGGGTTG } \\
\text { R: GGCCACCCAGATGTTGCAAAATG }\end{array}$ & 283 & $\begin{array}{l}G+123 A \\
T+198 C\end{array}$ & 62 & $\begin{array}{c}\text { BseNl } \\
\text { cfrl }\end{array}$ \\
\hline P4 & $\begin{array}{l}\text { F: CAGCCCATTCAGGTACGAGAGGA } \\
\text { R: ATTCGACTCTITGGGGCTGGAC }\end{array}$ & 793 & $\begin{array}{c}A+505 G \\
C+765 T \\
C+1011 T \\
G+1065 A \\
C+1107 T\end{array}$ & 65.5 & sequencing \\
\hline P5 & $\begin{array}{l}\text { F: TTCCCTTCATCCCCGTGCAGCT } \\
\text { R: GCTGCTTCTGTTGCCACTTGTGT }\end{array}$ & 290 & $+458 \sim+747$ & 63 & / \\
\hline P6 (actin) & $\begin{array}{l}\text { F: CCCCAAAGCCAACAGAGAGA } \\
\text { R: GGTGGTGAAGCTGTAGCCTCTC }\end{array}$ & 274 & / & 63 & / \\
\hline
\end{tabular}

${ }^{1}$ The length of PCR products; ${ }^{2}$ referred to the locations in the DRD1 gene, the first nucleotide of translation start codon was designated as $+1 .{ }^{3}$ indicated annealing temperature. 
Engineering Technology Company, Shanghai, China). The amplification was performed in a Eppendorf Mastercycler (Eppendorf Limited, Hamburg, Germany) under the following conditions: $94^{\circ} \mathrm{C}$ for $3 \mathrm{~min} ; 35$ cycles of $94^{\circ} \mathrm{C}$ for $30 \mathrm{~s}, \mathrm{n}^{\circ} \mathrm{C}$ for $45 \mathrm{~s}$ and $72^{\circ} \mathrm{C}$ for $1 \mathrm{~min}$; and $72^{\circ} \mathrm{C}$ for $10 \mathrm{~min}$. PCR products were subjected to a $1 \%$ agarose gel electrophoresis and visualized in TFM-40 Ultraviolet Transilluminator (UVP Company, Cambridge, UK) by ethidium bromide staining. Subsequently, the DNA bands were excised from the gel and purified with OMEGA Gel Extraction Kit (OMEGA Bio-Tek Inc., GA, American), and then subcloned into the pMD18-T vector (TaKaRa Biotechnology Co., Ltd., Dalian, China). DNA sequencing was performed by the dideoxy chain-termination method using dye terminator cycle sequencing on Applied Biosystem model 3730 sequencer. The analysis of sequences was conducted by the software DNASTAR V 3.0 (http://www.biologysoft. com/; Steve ShearDown, 1998-2001 version reserved by DNASTAR Inc., Madison, Wisconsin, USA).

\section{Genotyping of Polymorphisms}

Primers (P3 and P4) used for genotyping of polymorphisms in the DRD1 coding region were described in Table 2. Genotypes of $\mathrm{G}+123 \mathrm{~A}$ and $\mathrm{T}+198 \mathrm{C}$ were determined with PCR-RFLP method using genomic DNA from the 644 $\mathrm{NDH}$ individuals as templates. PCR products were subjected to digestion for $16 \mathrm{~h}$ at $37^{\circ} \mathrm{C}$ with the restriction enzyme BseNI and CfrI, respectively. The digestion mixture was composed of $8 \mu \mathrm{L}$ PCR products, $1 \times$ digestion buffer, and $3.0 \mathrm{U}$ of each enzyme. Subsequently the fragments were visualized by TFM-40 Ultraviolet Transilluminator (UVP Company, Cambridge, UK) following separation in $2.5 \%$ agarose gels and staining with ethidium bromide. For the other SNPs in the coding region, genotyping was carried out by direct sequencing.

\section{RNA Extraction and cDNA Synthesis}

Twelve NDH chickens, 6 broody individuals and 6 non-broody ones, were used in expression analysis. A total of 16 tissues, including heart, liver, spleen, lung, kidney, breast muscle, leg muscle, gizzard, glandular stomach, pituitary, hypothalamus, ovary, oviduct, duodenum, subcutaneous fat, and abdominal fat, were collected from each chicken. Among the 16 tissues, six tissues of pituitary, hypothalamus, ovary, oviduct, subcutaneous fat, and abdominal fat were important parts of chicken reproduction physiology system. Whereas other tissues including heart, liver, spleen, lung, kidney, breast muscle, leg muscle, gizzard, glandular stomach and duodenum were chosen to be the background tissues in chicken broodiness research. The dissected tissues were frozen in liquid nitrogen immediately and subsequently stored at $-80^{\circ} \mathrm{C}$ until used. Total RNA was extracted with TRIzol reagent (Invitrogen, Carlsbad, CA, USA) following the manufacturer's instructions and then treated with DNase (Promega, Madison, WI, USA). The DNase reaction were composed of $1 \mu \mathrm{g}$ of total RNA, $1 \mathrm{U}$ RNase-free DNase, $1 \mu \mathrm{L} 10 \times$ Reaction Buffer and $7 \mu \mathrm{L}$ nuclease-free water. The mixture was incubated at $37^{\circ} \mathrm{C}$ for $30 \mathrm{~min}$ followed by denaturation at $65^{\circ} \mathrm{C}$ for $10 \mathrm{~min}$ and snap cooled on ice for 2 min. The quality and purity of the RNA were checked by agarose gel electrophoresis and spectrophotometry. cDNA was synthesized in a final volume of 20 $\mu \mathrm{L}$ including $1 \mu \mathrm{g}$ of total RNA, $1 \times$ MMLV Buffer, 1 $\mathrm{mM}$ of each dNTPs, $2.5 \mu \mathrm{M}$ oligo $(\mathrm{dT})_{18}, 0.5 \mu \mathrm{L}(40 \mathrm{U} /$ $\mu \mathrm{l})$ RNase inhibitor, $100 \mathrm{U}$ MMLV SuperScript III reverse transcriptase (Invitrogen, Carlsbad, CA, USA). The reverse transcription was processed for $40 \mathrm{~min}$ at $42^{\circ} \mathrm{C}$ followed by heating for $5 \mathrm{~min}$ at $95^{\circ} \mathrm{C}$ and cooling on ice.

\section{Quantitative Real-Time PCR}

Quantitative real-time PCR (qPCR) was performed with the ABI PRISM 7000 sequence detection system (Applied Biosystems, Foster City, CA, USA) using the SYBR Green PCR Master Mix. The obtained cDNAs were used as templates for qPCR amplification. Primers used for the qPCR were designed by Primer Express 2.0 software (Applied Biosystems, Foster City, CA, USA). A housekeeping gene, chicken $\beta$-actin gene [GenBank: LOC396526], was used as internal control. Therefore, two sets of primers (shown in Table 2), P5 and P6, were designed and used for the qPCR amplification of chicken $D R D 1$ gene and chicken $\beta$-actin gene, respectively. Each reaction mixture contained $10 \mu \mathrm{L}$ of SYBR Green PCR Master Mix, $2 \mu \mathrm{L}$ of each primer (10 $\mu \mathrm{M}), 4 \mu \mathrm{L}$ ultrapure RNase-free water and $2 \mu \mathrm{L}$ of cDNA in a final volume of $20 \mu \mathrm{L}$. Standard amplification conditions were as follows: $95^{\circ} \mathrm{C}$ for $3 \mathrm{~min} ; 40$ cycles of $95^{\circ} \mathrm{C}$ for $30 \mathrm{~s}, 63^{\circ} \mathrm{C}$ for $30 \mathrm{~s}$ and $72^{\circ} \mathrm{C}$ for $40 \mathrm{~s}$. Fluorescent signal were collected after the extension at $72^{\circ} \mathrm{C}$ in each cycle. Amplification of DRD1 and $\beta$-actin for each sample was run simultaneously in separate tubes and in duplicates. A negative control with sterile water as template was run for each primer in order to control the reagent contamination. The whole experiment was repeated at least twice. After amplification, dissociation curve analysis was conducted to ensure only one product. And then the product was sequenced to confirm amplification of the correct sequences.

\section{Statistical Analysis \\ Identification of the Chicken DRD1 Gene Polymorphisms and Prediction of the Transcription Factor Binding Sites in the 5' Flanking Region}

DNAMAN (Lynnon Biosoft) was used for DNA contig assembly, sequence editing, and sequence translation. 
The identification of mutated sites was performed by MegAlign program of DNASTAR software (http://www. biologysoft.com/; Steve ShearDown, 1998-2001 version reserved by DNASTAR Inc., Madison, Wisconsin, USA). The potential transcription factor binding sites of the 5'flanking region polymorphisms were predicted by two bioinformatic websites of http://motif.genome.jp and http://www.gene-regulation.com/pub/programs/alibaba2 following the setting parameters. The same results identified by the two websites were finally chosen.

Haplotype Inference and Marker -Trait Association Analysis Hardy-Weinberg's equilibrium and the haplotype structure were analyzed by Haploview version 3.32 software http://www.broad.mit.edu/mpg/haploview/) [37]. Haplotypes were inferred based on the haplotype structure by the PHASE 2.0 software http://www.stat.washington. edu/stephens/software.html[38].

Association analysis of polymorphisms or haplotypes with egg production and broodiness traits were conducted by SAS GLM procedure (SAS Institute Inc., Cary, NC, USA) using the following model:

$$
\mathrm{Y}_{\mathrm{ij}}=\mu+\mathrm{G}_{\mathrm{i}}+\mathrm{H}_{\mathrm{j}}+\mathrm{e}_{\mathrm{ij}}
$$

Where $Y_{i j}$ is an observation on the traits, $\mu$ is the overall population mean, $G_{i}$ is the effect of genotype, $H_{j}$ is the fixed effect of hatch and the $e_{i j}$ is the residual error. Multiple comparisons were performed with least squares means using the following procedure:

$$
Y_{i}-\bar{Y}_{i}=\left(Y_{i}-\hat{Y}_{i}\right)+\left(\hat{Y}_{i}-\bar{Y}_{i}\right)
$$

Where $\sum\left(Y_{i}-\hat{Y}_{i}\right)^{2}$ is the least value, and $\sum\left(Y_{i}-\hat{Y}_{i}\right)^{2}=0$. The results were presented as least square means \pm standard error.

The comparisons of broody frequency among different genotypes or diplotypes in each site were evaluated by chi-square $\left(\chi^{2}\right)$ tests performed on a $2 \times 3$ (or $n$ ) contingency table. A $\mathrm{P} \leq 0.05$ was considered statistically significant in all analysis.

\section{Expression Analysis of DRD1 mRNA}

Quantitative values were obtained from the threshold cycle $(\mathrm{Ct})$ at which a significant increase in the magnitude of the signal generated by the PCR reaction started to be detected. The relative amount of chicken DRD1 mRNA in each tissue was calculated by the formula $2^{-\Delta \Delta \mathrm{Ct}}$ [39], where $\Delta \Delta \mathrm{Ct}$ corresponded to the difference between the $\Delta \mathrm{Ct}$ measured for the mRNA level of each tissue and that measured for the mRNA level of reference tissue (the hypothalamus of non-broody chicken). Here $\Delta \mathrm{Ct}=\mathrm{Ct}_{\text {target }}$ gene $-\mathrm{Ct}_{\beta \text {-actin }}$. Results were expressed as means \pm standard error means. Statistical analyses of differences in distinct tissues were processed with least square method by SAS 8.0 software (SAS Institute Inc., Cary, NC, USA). Significant differences between broody and non-broody chickens were detected using Student t test at a significance level of 0.05 in each tissue.

\section{Results}

Polymorphisms of the Chicken DRD1 Gene and Transcription Factor Binding Sites Prediction in the $\mathbf{5}^{\prime}$ Flanking Region

Twenty-seven single nucleotide polymorphisms (SNPs) and 2 indel variations (shown in Table 3 ) were identified in a total of 3,342 bp region of the chicken DRD1 gene, among which 7 SNPs were located in coding region and others in the 5' regulatory region. In the full region studied, on average every 115 bp generated one SNP. The polymorphism density of the coding region was just one SNP per $194 \mathrm{bp}$, and in the 5' regulatory region it was one per $89 \mathrm{bp}$. Among the 7 SNPs (shown in Table 4) in the coding region, only one SNP was non-synonymous mutation (A+505G, Ser169Gly) and located in

\section{Table 3 Polymorphisms detected in the chicken DRD1}

\begin{tabular}{|c|c|c|c|c|c|}
\hline No. & Variation $^{1}$ & region & No. & Variation $^{1}$ & region \\
\hline 1 & A-1793C & $\begin{array}{l}5^{\prime} \text { regulatory } \\
\text { region }\end{array}$ & 16 & A-647G & $\begin{array}{c}5^{\prime} \text { regulatory } \\
\text { region }\end{array}$ \\
\hline 2 & G-1735C & $\begin{array}{l}5^{\prime} \text { regulatory } \\
\text { region }\end{array}$ & 17 & $C-634 G$ & $\begin{array}{c}5^{\prime} \text { regulatory } \\
\text { region }\end{array}$ \\
\hline 3 & C-1687T & $\begin{array}{l}5^{\prime} \text { regulatory } \\
\text { region }\end{array}$ & 18 & A-570G & $\begin{array}{c}5^{\prime} \text { regulatory } \\
\text { region }\end{array}$ \\
\hline 4 & T-1679C & $\begin{array}{l}5^{\prime} \text { regulatory } \\
\text { region }\end{array}$ & 19 & G-454A & $\begin{array}{c}5^{\prime} \text { regulatory } \\
\text { region }\end{array}$ \\
\hline 5 & G-1591C & $\begin{array}{l}5^{\prime} \text { regulatory } \\
\text { region }\end{array}$ & 20 & T-349C & $\begin{array}{c}5^{\prime} \text { regulatory } \\
\text { region }\end{array}$ \\
\hline 6 & G-1463C & $\begin{array}{l}5^{\prime} \text { regulatory } \\
\text { region }\end{array}$ & 21 & $\begin{array}{l}-225 \mathrm{~A} \\
\text { indel }\end{array}$ & $\begin{array}{c}5^{\prime} \text { regulatory } \\
\text { region }\end{array}$ \\
\hline 7 & A-1412T & $\begin{array}{l}5^{\prime} \text { regulatory } \\
\text { region }\end{array}$ & 22 & A-179T & $\begin{array}{c}5^{\prime} \text { regulatory } \\
\text { region }\end{array}$ \\
\hline 8 & $\begin{array}{c}-1157 C \\
\text { indel }\end{array}$ & $\begin{array}{l}5^{\prime} \text { regulatory } \\
\text { region }\end{array}$ & 23 & $G+123 A$ & Exon \\
\hline 9 & C-1029T & $\begin{array}{l}5^{\prime} \text { regulatory } \\
\text { region }\end{array}$ & 24 & $\mathrm{~T}+198 \mathrm{C}$ & Exon \\
\hline 10 & G-995A & $\begin{array}{l}5^{\prime} \text { regulatory } \\
\text { region }\end{array}$ & 25 & $A+505 G$ & Exon \\
\hline 11 & A-942G & $\begin{array}{l}5^{\prime} \text { regulatory } \\
\text { region }\end{array}$ & 26 & $C+765 T$ & Exon \\
\hline 12 & T-941C & $\begin{array}{l}5^{\prime} \text { regulatory } \\
\text { region }\end{array}$ & 27 & $\mathrm{C}+1011 \mathrm{~T}$ & Exon \\
\hline 13 & A-910G & $\begin{array}{l}5^{\prime} \text { regulatory } \\
\text { region }\end{array}$ & 28 & $G+1065 A$ & Exon \\
\hline 14 & $\mathrm{~T}-823 \mathrm{G}$ & $\begin{array}{l}5^{\prime} \text { regulatory } \\
\text { region }\end{array}$ & 29 & $C+1107 T$ & Exon \\
\hline 15 & $C-684 \mathrm{~A}$ & $\begin{array}{l}5^{\prime} \text { regulatory } \\
\text { region }\end{array}$ & & & \\
\hline
\end{tabular}
gene

${ }^{1}$ the first nucleotide of translation start codon was designated as +1 . 
Table 4 Detail information for polymorphisms in the DRD1 coding region

\begin{tabular}{cccccc}
\hline SNP $^{\mathbf{1}}$ & AA Variation & Location $^{\mathbf{2}}$ & SNP $^{\mathbf{1}}$ & AA Variation $^{\text {Location }}{ }^{\mathbf{2}}$ \\
\hline $\mathrm{G}+123 \mathrm{~A}$ & Thr41Thr & TM I & $\mathrm{C}+1011 \mathrm{~T}$ & Asn337Asn & $\mathrm{CT}$ \\
$\mathrm{T}+198 \mathrm{C}$ & Ala66Ala & TM II & $\mathrm{G}+1065 \mathrm{~A}$ & Pro355Pro & $\mathrm{CT}$ \\
$\mathrm{A}+505 \mathrm{G}$ & Ser169Gly & Extracellular domain & $\mathrm{C}+1107 \mathrm{~T}$ & Asn369Asn & $\mathrm{CT}$ \\
$\mathrm{C}+765 \mathrm{~T}$ & Pro255Pro & The third intracellular loop & & & \\
\hline
\end{tabular}

${ }^{1}$ the first nucleotide of translation start codon was designated as $+1 .{ }^{2} \mathrm{TM} \mathrm{I}=$ transmembrane domain I; TM II = transmembrane domain II; CT = the carboxylic tail.

the second extracellular domain. Three synonymous polymorphisms, $\mathrm{C}+1011 \mathrm{~T}, \mathrm{G}+1065 \mathrm{~A}$, and $\mathrm{C}+1107 \mathrm{~T}$, were located in the carboxylic tail of DRD1. The variations of $\mathrm{G}+123 \mathrm{~A}, \mathrm{~T}+198 \mathrm{C}$, and $\mathrm{C}+765 \mathrm{~T}$, occurred in transmembrane domain I, transmembrane domain II, and the third intracellular loop, respectively.

The analysis of the DRD1 5' flanking region showed that multiple putative binding sites for transcription factors Sp1, AP1 and AP2 were detected, but no TATA and CAAT boxes were found in the presumptive promoter. By online prediction, 5 mutations in the 5' flanking region were found to be related with mutations of transcription factor binding sites. A-570G led to a GATA-1 binding site to disappear. A-647G induced the change from a SRY binding site to a HSF binding site. C-684A induced the change from a SRY site to HFH-3, Croc, $\mathrm{Hb}, \mathrm{CdxA}$ binding sites. $\mathrm{C}$ indel located at -1157 generated a putative HSF binding site. G-1735C resulted in the loss of an ADR1 binding site and the gain of an E2F site.

\section{Genotype and Haplotype Structure}

Seven SNPs in the coding region of the chicken DRD1 gene were genotyped in the NDH population. No polymorphism was detected in A+505G, whereas, in each of the other 6 SNPs, three genotypes were found in this population. Haplotype structure analysis showed that there were 2 haplotype blocks for the 6 SNPs. The corresponding base combinations for each haplotype block were shown in Table 5 . Block 1 was composed of $\mathrm{G}$ $+123 \mathrm{~A}$ and $\mathrm{T}+198 \mathrm{C}$ and three haplotypes with frequencies higher than 1\%, including $\mathrm{H} 2$ (AC, 21.28\%), H3 (GT, 70.49\%) and H4 (GC, 7.44\%), were observed. Block 2 comprised $\mathrm{G}+1065 \mathrm{~A}$ and $\mathrm{C}+1107 \mathrm{~T}$. Three haplotypes with frequencies higher than 1\%, E2 (AC, 57.47\%), E3
(GT, 18.26\%), and E4 (GC, 24.11\%), were found in this block.

\section{Association of Polymorphisms in the DRD1 Coding Region with Chicken Egg Production and Broodiness Traits}

The G+123A was significantly associated with chicken broody frequency $(P<0.05)$. Furthermore, the EN values of chickens with the AA genotype were significantly higher than those with the GG genotype ( $\mathrm{P}<$ 0.05) (Table 6). $\mathrm{C}+1107 \mathrm{~T}$ was in significant association $(\mathrm{P}<0.05)$ with chicken broody frequency (Table 7$)$. No significant association was found in the other 4 markers (A-179T, T+198C, C+765T, and G+1065A) with chicken egg production and broodiness traits $(\mathrm{P}>0.05)$.

\section{Association of the Haplotypes with Chicken Egg \\ Production and Broodiness Traits}

A total of 623 individuals with 6 diplotypes (30 of $\mathrm{H} 2 \mathrm{H} 2,178$ of $\mathrm{H} 2 \mathrm{H} 3,31$ of $\mathrm{H} 2 \mathrm{H} 4,324$ of $\mathrm{H} 3 \mathrm{H} 3,57$ of $\mathrm{H} 3 \mathrm{H} 4,3$ of $\mathrm{H} 4 \mathrm{H} 4$ ) were used in association analysis in the block 1. Significant association $(P=0.03)$ of the haplotypes of $\mathrm{G}+123 \mathrm{~A}$ and $\mathrm{T}+198 \mathrm{C}$ with EW was observed. $\mathrm{H} 2 \mathrm{H} 4$ had much lower value of EW (mean = $44.1 \mathrm{~g})$ and was highly significantly different $(\mathrm{P}<0.01)$ from $\mathrm{H} 2 \mathrm{H} 3$, significantly $(\mathrm{P}<0.05)$ from $\mathrm{H} 3 \mathrm{H} 4$. Nevertheless, H2H2 had much higher value of EN (mean = 124.0) and QEN (mean = 118.9) and was significantly different from H3H3 $(\mathrm{P}=0.04)$ and $\mathrm{H} 4 \mathrm{H} 4(\mathrm{P}=0.02)$, respectively.

A total of 614 individuals with 6 diplotypes (200 of E2E2, 134 of E2E3, 174 of E2E4, 11 of E3E3, 67 of E3E4, 28 of E4E4) were used in association analysis in the block 2. The haplotypes of $\mathrm{G}+1065 \mathrm{~A}$ and $\mathrm{C}+1107 \mathrm{~T}$ were significantly associated $\left(\chi^{2}\right.$ value $(\mathrm{df}=5)=11.08$,

Table 5 The corresponding base combinations for two haplotype blocks

\begin{tabular}{|c|c|c|c|c|c|c|c|}
\hline $\begin{array}{c}\text { Block } 1 \\
\text { Haplotype }\end{array}$ & $\mathrm{G}+123 \mathrm{~A}$ & $\mathrm{~T}+198 \mathrm{C}$ & Frequency & $\begin{array}{c}\text { Block } 2 \\
\text { Haplotype }\end{array}$ & $G+1065 A$ & $\mathrm{C}+1107 \mathrm{~T}$ & Frequency \\
\hline $\mathrm{H} 1(\mathrm{AT})$ & A & $T$ & 0.0079 & E1(AT) & A & $T$ & 0.0016 \\
\hline $\mathrm{H} 2(\mathrm{AC})$ & A & C & 0.2128 & $E 2(A C)$ & A & C & 0.5747 \\
\hline $\mathrm{H} 3(\mathrm{GT})$ & G & T & 0.7049 & $\mathrm{E} 3(\mathrm{GT})$ & G & $\mathrm{T}$ & 0.1826 \\
\hline $\mathrm{H} 4(\mathrm{GC})$ & G & C & 0.0744 & $\mathrm{E} 4(\mathrm{GC})$ & G & C & 0.2411 \\
\hline
\end{tabular}


Table 6 Association of the G+123A with egg production traits and broody traits in Ningdu Sanhuang Chickens

\begin{tabular}{ccccc}
\hline Traits $^{\mathbf{1}}$ & $\mathbf{P}$ value & $\mathbf{G G}^{\mathbf{2}} \mathbf{( 3 8 5 )}$ & $\mathbf{A G}^{\mathbf{2}} \mathbf{( 2 1 7 )}$ & $\mathbf{A A}^{\mathbf{2}} \mathbf{( 3 1 )}^{\mathrm{a}}$ \\
\hline AFE(d) & 0.58 & $135.7 \pm 0.6^{\mathrm{a}}$ & $136.3 \pm 0.7^{\mathrm{a}}$ & $137.3 \pm 1.9^{\mathrm{a}}$ \\
$\mathrm{EN}$ & 0.10 & $113.3 \pm 1.5^{\mathrm{a}}$ & $114.6 \pm 1.9^{\mathrm{ab}}$ & $124.2 \pm 4.9^{\mathrm{b}}$ \\
QEN & 0.17 & $109.8 \pm 1.5^{\mathrm{a}}$ & $110.3 \pm 1.8^{\mathrm{a}}$ & $119.2 \pm 4.8^{\mathrm{a}}$ \\
OEN & 0.14 & $3.6 \pm 0.3^{\mathrm{a}}$ & $4.3 \pm 0.4^{\mathrm{a}}$ & $5.0 \pm 1.0^{\mathrm{a}}$ \\
EW (g) & 0.89 & $45.8 \pm 0.2^{\mathrm{a}}$ & $45.7 \pm 0.3^{\mathrm{a}}$ & $45.5 \pm 0.6^{\mathrm{a}}$ \\
DB(d) & 0.35 & $7.9 \pm 0.8^{\mathrm{a}}$ & $7.0 \pm 1.0^{\mathrm{a}}$ & $4.4 \pm 2.5^{\mathrm{a}}$ \\
Number of nonbroody chickens & $/$ & 186 & 116 & 22 \\
Number of broody chickens & $/$ & 199 & 46.54 & 9 \\
Broody frequency (\%) & $/$ & 51.69 & & 29.03 \\
$\chi^{2}$ value & $<0.05$ & $6.58^{*}$ & \\
\hline
\end{tabular}

${ }^{1} \mathrm{AFE}=$ age of first egg; EN = total egg number from 90 to $300 \mathrm{~d}$ of age; QEN = total number of qualified eggs from 90 to $300 \mathrm{~d}$ of age; OEN = total number of oafish eggs from 90 to $300 \mathrm{~d}$ of age; $\mathrm{EW}=$ weight of first egg; $\mathrm{DB}=$ duration days of broodiness. ${ }^{2}$ Least-square means \pm standard errors (SE); Number in brackets referred to the number of tested chickens of each genotype. ${ }^{\mathrm{a}}{ }^{\mathrm{b}}$ means within a row with no common superscript are different significantly ( $\left.\mathrm{P}<0.05\right)$. ${ }^{*}$ indicated $P<0.05 . \chi^{2}{ }_{0.05}(\mathrm{df}=2)=5.99$.

Table 7 Association of the $C+1107 T$ with egg production traits and broody traits in Ningdu Sanhuang Chickens

\begin{tabular}{|c|c|c|c|c|}
\hline Traits $^{1}$ & $P$ value & $\mathrm{CC}^{2}(403)$ & $\mathrm{TC}^{2}(201)$ & $T^{2}(13)$ \\
\hline $\mathrm{AFE}(\mathrm{d})$ & 0.24 & $136.0 \pm 0.6$ & $135.7 \pm 0.7$ & $140.7 \pm 2.9$ \\
\hline EN & 0.27 & $113.6 \pm 1.5$ & $115.1 \pm 2.0$ & $125.5 \pm 7.6$ \\
\hline QEN & 0.36 & $109.8 \pm 1.4$ & $110.9 \pm 1.9$ & $120.3 \pm 7.4$ \\
\hline OEN & 0.37 & $3.7 \pm 0.3$ & $4.2 \pm 0.4$ & $5.3 \pm 1.5$ \\
\hline EW (g) & 0.88 & $45.8 \pm 0.2$ & $45.8 \pm 0.3$ & $45.3 \pm 0.9$ \\
\hline Duration of broodiness (d) & 0.85 & $7.5 \pm 0.7$ & $7.3 \pm 1.0$ & $5.3 \pm 3.9$ \\
\hline Number of nonbroody chickens & / & 195 & 108 & 11 \\
\hline Number of broody chickens & / & 208 & 93 & 2 \\
\hline Broody frequency (\%) & / & 51.61 & 46.27 & 15.38 \\
\hline$\chi^{2}$ value & $<0.05$ & $7.58^{*}$ & & \\
\hline
\end{tabular}

${ }^{1} \mathrm{AFE}=$ age of first egg; $\mathrm{EN}=$ total egg number from 90 to $300 \mathrm{~d}$ of age; QEN = total number of qualified eggs from 90 to $300 \mathrm{~d}$ of age; OEN = total number of oafish eggs from 90 to $300 \mathrm{~d}$ of age; $\mathrm{EW}=$ weight of first egg; $\mathrm{DB}=$ duration days of broodiness. ${ }^{2}$ Least-square means \pm standard errors (SE); Number in brackets referred to the number of tested chickens of each genotype. ${ }^{a}$, ${ }^{b}$ means within a row with no common superscript are different significantly $(P<0.05) .{ }^{*}$ indicated $P<0.05 . \chi_{0.05}^{2}(\mathrm{df}=2)=5.99$.

$0.01<\mathrm{P}<0.05)$ with broody frequency. Nevertheless, E3E3 had much higher value of AFE (mean = 142.2) than other diplotypes and was significantly different with E2E2, E2E3, and E3E4 $(\mathrm{P}<0.05)$.

\section{Tissue-specific Expression of the DRD1 and the mRNA Comparison between Broodiness and Non-broodiness Chickens}

The DRD1 mRNA was differentially expressed in distinct tissues (Figure 1). There was almost no mRNA present in gizzard. Low mRNA level was observed in liver, spleen, lung, breast muscle, leg muscle, as well as in duodenum. Instead, much higher levels of the DRD1 expression were detected in tissues such as heart, kidney, oviduct, glandular stomach, hypothalamus, and pituitary. Remarkably, the highest levels of the DRD1 expression were found in subcutaneous fat of non-broodiness chickens, and then abdominal fat.

In subcutaneous fat and abdominal fat, significantly difference of the DRD1 mRNA was found between broodiness and non-broodiness chickens $(\mathrm{P}<0.05)$. The level of non-broodiness was 26 to 28 times higher than that of broodiness. The expression of non-broodiness was observed to be 5 -fold greater than that of broodiness in pituitary. Also a prominent decrease from nonbroodiness to broodiness was displayed in heart, oviduct, and kidney. In these tissues, the expression of non-broodiness was 2-3 times higher as compared to that of broodiness. The level of glandular stomach seen in nonbroodiness was almost the same as in broodiness. Similarly, the same level was found in non-broodiness and broodiness hypothalamus (Figure 1).

\section{Discussion}

In this study, abundant polymorphisms were found in the chicken $D R D 1$ gene. Soller reported that SNP frequencies in poultry species ranged from 1:48 to $1: 1632$ bp [40]. Here SNP frequency of the chicken DRD1 gene was 1:115 bp and it was similar to previous study [41]. In this study, the absence of TATA and CAAT boxes 


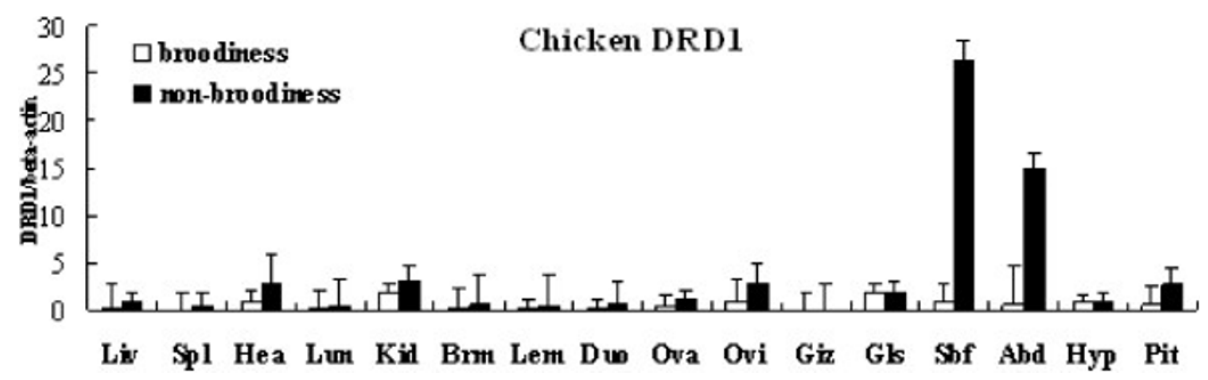

Figure 1 The distribution of DRD1 mRNA in broodiness and non-broodiness chickens. The horizontal axis and vertical axis indicate different tissues and $2^{-\Delta \Delta C t}$ value (mean \pm SEM), respectively. Liv $=$ liver, Spl = spleen, Hea = heart; Lun = lung, Kid = kidney, Brm = breast muscle, Lem = leg muscle, Duo = duodenum, Ova = ovary, Ovi = oviduct, Giz = gizzard, Gls= glandular stomach, Sbf = subcutaneous fat, Abd = abdominal fat, Hyp = hypothalamus, Pit = pituitary.

was found in chicken $D R D 1$ promoter, as reported in human [42]. Mutations in the promoter region can cause changes of transcription factor binding sites and consequently may affect the transcription and the phenotype [43]. In the 5' flanking region of the chicken $D R D 1$ gene, there were multiple putative binding sites for transcription factor $\mathrm{Sp} 1$ and consensus sequences for AP1 and AP2 binding sites. It was consistent with the analysis of human DRD1 gene [44].

A variety of structural variations occurred in different regions of $\mathrm{G}$ protein coupled receptor proteins have been found to be related with diseases $[45,46]$. In the present study, one non-synonymous mutation (Ser169Gly) was present in the extracellular domain. As no polymorphism of this site was observed in the NDH population, its effects on chicken egg production and broodiness still required further study in other populations.

SNP in cytoplasmic tail and transmembrane I seemed to have great effects on egg production and broodiness. In this study, three mutations found within the cytoplasmic tail of the chicken $D R D 1$ gene might cause the change of various functions even if they were synonymous. $\mathrm{C}+1107 \mathrm{~T}$, a mutation located in the cytoplasmic tail, was found to be associated with chicken broodiness, and haplotype analysis also provided similar results. In addition, $\mathrm{G}+123 \mathrm{~A}$, a variation in transmembrane $\mathrm{I}$ of the $D R D 1$ gene, was associated with chicken egg production and broodiness traits. The polymorphisms of $\mathrm{G}$ $+123 \mathrm{~A}$ and $\mathrm{C}+1107 \mathrm{~T}$ may be acted as Marker assistant selection (MAS) markers of reducing incidence of broodiness and improving egg production in modern poultry industry. In the same NDH population of our former study, two SNPs of the chicken DRD2 gene, A-16105G and $T+619 \mathrm{C}$, were also found to be significantly associated with broody frequency and duration of broodiness, respectively [47].

Other studies also indicated that the cytoplasmic tail of D1-like receptors, especially the $\mathrm{N}$-terminal segment termed as the fourth intracellular loop, played a crucial role in the regulation of the activation of adenylyl cyclase, ligand binding, expression, and $\mathrm{G}$ protein coupling properties [48-52]. Members of G protein coupled receptors displayed considerable amino acid sequence conservation within transmembrane domains [53]. Through bioinformatics analysis, the presumed transmembrane domains of the DRD1 gene were proved to be highly conserved in diverse species. Many previous studies reported that some mutants present in transmembrane domains of the Dl receptor affect ligand interactions and receptor signal transduction [54-56]. It seemed that the variation may play a crucial role on egg production and broodiness traits by affecting ligand binding or signal transduction.

In mammals, the $D R D 1$ gene was found to express in the tissues of striatum, nucleus accumbens, cerebral cortex, amygdale, olfactory tubercle, retina, limbic system, hypothalamus, and thalamus $[57,58]$, but not in cerebellum, hippocampus, mesencephalon, pituitary, kidney, liver, lung and heart tissues $[42,59,60]$. In avian, it was revealed that the distribution of the DRD1 gene in the forebrain was substantially similar to that of mammals [61]. In this study, similar to mammals, high level of the chicken DRD1 mRNA was detected in the hypothalamus. However, high to moderate DRD1 mRNA were also detected in chicken heart, kidney, oviduct, glandular stomach, hypothalamus, pituitary, and adipose tissues and a considerably low but still detectable expression was found in liver, spleen, lung, muscle, and duodenum.

The level of the DRD1 mRNA was quantified in the brain of the domestic turkey hen during the reproductive cycle and it was expressed throughout the hypothalamus and pituitary [35]. But no significant difference of DRD1 mRNA abundance was observed in hypothalamic and pituitary throughout the reproductive cycle. Similarly, this study suggested that in hypothalamus, as well as in glandular stomach, the DRD1 mRNA levels seen in broody chickens were essentially the same as in 
non-broody ones. However, higher DRD1 mRNA content was found in pituitary (5-fold), heart (3-fold), oviduct (2.8-fold), and kidney (2-fold) of non-broody hens as compared to that of incubating hyperprolactinemic hens. In particular, it was interesting that there was a dramatic expression difference in adipose tissues from non-broodiness to broodiness stage. The level of the $D R D 1$ mRNA in non-broody chickens was 26 to 28 times greater than that of broody chickens in adipose tissues including subcutaneous fat and abdominal fat. As chickens in broodiness had lower fatty content compared with non-broody chickens, the subtle decreased mRNA in broody chickens suggested that DRD1 was probably involved in fat deposition. In general, a high abundance of DRD1 mRNA was found in non-broodiness compared with broodiness in each tissue, except for the glandular stomach and hypothalamus. All these findings indicated that the DRD1 gene was probably related to chicken broodiness.

\section{Conclusions}

In summary, the results of association analysis and the expression comparison of broody chickens with nonbroody chickens demonstrated that the DRD1 had important effects on chicken egg production and broodiness incidence.

\section{Acknowledgements}

This study was supported by a grant from the National Natural Scientific Foundation of China, project no. 30471241, a grant from the Major State Basic Research Development Program of China, project no. 2006CB102107 and a grant from the National High Technology Research and Development Program of China (863 Program), project no. 2006AA10A120.

\section{Author details}

'Department of Animal Genetics, Breeding and Reproduction, College of Animal Science, South China Agricultural University, Guangzhou 510642, Guangdong, China. ${ }^{2}$ Biotechnology Institute, Jiang Xi Education College, Nanchang 330029, Jiangxi, China. ${ }^{3}$ Department of Laboratory Animal Science, Medical College of Jinan University, Guangzhou 510632, Guangdong, China.

\section{Authors' contributions}

HX carried out the mRNA research, analyzed the data and drafted the manuscript. XS contributed to the genotyping of most of the SNP, MZ and MF participated in the data analyses. $\mathrm{HZ}$ contributed to materials collection. QN and XZ contributed to the design of the study, the supervision of the study and the revision of this manuscript. All authors read and approved the final manuscript.

Received: 7 August 2009 Accepted: 3 March 2010 Published: 3 March 2010

\section{References}

1. Sharp PJ, Dawson A, Lea RW: Control of luteinizing hormone and prolactin secretion in birds. Comp Biochem Physiol C Pharmacol Toxicol Endocrinol 1998, 119:275-282.

2. Sharp PJ: Genes for persistency of egg laying: White Leghorns and broodiness. Roslin Institute Edinburgh Annual Report 2004, 38-42.
3. Romanov MN, Talbot RT, Wilson PW, Sharp PJ: Inheritance of broodiness in the domestic fowl. Br Poult Sci 1999, 40(Suppl):20-21.

4. Romanov MN, Talbot RT, Wilson PW, Sharp PJ: Genetic control of incubation behavior in the domestic hen. Poult Sci 2002, 81:928-931.

5. Cui JX, Du HL, Liang Y, Deng XM, Li N, Zhang XQ: Association of polymorphisms in the promoter region of chicken prolactin with egg production. Poult Sci 2006, 85:26-31.

6. Jiang RS, Xu GY, Zhang XQ, Yang N: Association of polymorphisms for prolactin and prolactin receptor genes with broody traits in chickens. Poult Sci 2005, 84:839-845.

7. Liang Y, Cui J, Yang G, Leung FC, Zhang X: Polymorphisms of $5^{\prime}$ flanking region of chicken prolactin gene. Domest Anim Endocrinol 2006, 30:1-16.

8. Zhou M, Lei M, Rao Y, Nie Q, Zeng H, Xia M, Liang F, Zhang D, Zhang X: Polymorphisms of vasoactive intestinal peptide receptor-1 gene and their genetic effects on broodiness in chickens. Poult Sci 2008, 87:893-903.

9. Sharp PJ, Macnamee MC, Sterling RJ, Lea RW, Pedersen HC: Relationships between prolactin, $\mathrm{LH}$ and broody behaviour in bantam hens. $J$ Endocrinol 1988, 118:279-286.

10. el Halawani ME, Silsby JL, Youngren OM, Phillips RE: Exogenous prolactin delays photo-induced sexual maturity and suppresses ovariectomyinduced luteinizing hormone secretion in the turkey (Meleagris gallopavo). Biol Reprod 1991, 44:420-424.

11. el Halawani ME, Silsby JL, Behnke EJ, Fehrer SC: Hormonal induction of incubation behavior in ovariectomized female turkeys (Meleagris gallopavo). Biol Reprod 1986, 35:59-67.

12. March JB, Sharp PJ, Wilson PW, Sang HM: Effect of active immunization against recombinant-derived chicken prolactin fusion protein on the onset of broodiness and photoinduced egg laying in bantam hens. J Reprod Fertil 1994, 101:227-233.

13. Ben-Jonathan N, Hnasko R: Dopamine as a prolactin (PRL) inhibitor. Endocr Rev 2001, 22:724-763.

14. Reymond MJ, Porter JC: Involvement of hypothalamic dopamine in the regulation of prolactin secretion. Horm Res 1985, 22:142-152.

15. Xu M, Proudman JA, Pitts GR, Wong EA, Foster DN, el Halawani ME: Vasoactive intestinal peptide stimulates prolactin mRNA expression in turkey pituitary cells: effects of dopaminergic drugs. Proc Soc Exp Biol Med 1996, 212:52-62.

16. Cools R: Role of dopamine in the motivational and cognitive control of behavior. Neuroscientist 2008, 14:381-395.

17. Nieoullon A, Coquerel A: Dopamine: a key regulator to adapt action, emotion, motivation and cognition. Curr Opin Neurol 2003, 16(Suppl 2):3-9.

18. Hansen KA, Zhang Y, Colver R, Tho SP, Plouffe L Jr, McDonough PG: The dopamine receptor D2 genotype is associated with hyperprolactinemia. Fertil Steril 2005, 84:711-718.

19. Missale C, Nash SR, Robinson SW, Jaber M, Caron MG: Dopamine receptors: from structure to function. Physiol Rev 1998, 78:189-225.

20. Kebabian JW, Calne DB: Multiple receptors for dopamine. Nature 1979, 277:93-96.

21. Gingrich JA, Caron MG: Recent advances in the molecular biology of dopamine receptors. Annu Rev Neurosci 1993, 16:299-321.

22. Seeman P, Van Tol HH: Dopamine receptor pharmacology. Trends Pharmacol Sci 1994, 15:264-270.

23. Youngren OM, Pitts GR, Phillips RE, el Halawani ME: The stimulatory and inhibitory effects of dopamine on prolactin secretion in the turkey. Gen Comp Endocrinol 1995, 98:111-117.

24. Porter TE, Grandy D, Bunzow J, Wiles CD, Civelli O, Frawley LS: Evidence that stimulatory dopamine receptors may be involved in the regulation of prolactin secretion. Endocrinology 1994, 134:1263-1268.

25. Youngren OM, Pitts GR, Phillips RE, el Halawani ME: Dopaminergic control of prolactin secretion in the turkey. Gen Comp Endocrinol 1996, 104:225-230.

26. Youngren O, Chaiseha Y, Al-Zailaie K, Whiting S, Kang SW, El Halawani M: Regulation of prolactin secretion by dopamine at the level of the hypothalamus in the turkey. Neuroendocrinology 2002, 75:185-192.

27. Youngren OM, Chaiseha Y, El Halawani ME: Regulation of prolactin secretion by dopamine and vasoactive intestinal peptide at the level of the pituitary in the turkey. Neuroendocrinology 1998, 68:319-325. 
28. Al Kahtane A, Chaiseha Y, El Halawani M: Dopaminergic regulation of avian prolactin gene transcription. J Mol Endocrinol 2003, 31:185-196.

29. Hall TR, Chadwick A: Dopaminergic inhibition of prolactin release from pituitary glands of the domestic fowl incubated in vitro. J Endocrinol 1984, 103:63-69.

30. Millam JR, Burke WH, El Halawani ME, Ogren LA: Preventing broodiness in turkey hens with a dopamine receptor blocking agent. Poult Sci 1980, 59:1126-1131.

31. Shi ZD, Liang SD, Bi YZ: Studies on the role of hypothalamic dopamine and 5-hydroxytryptamine in regulation of broodiness in chicken hens. Proceedings of international conference on bird reproduction: 22-24 September 1999; Tours, France.

32. Sartsoongnoen N, Kosonsiriluk S, Prakobsaeng N, Songserm T, Rozenboim I, Halawani ME, Chaiseha Y: The dopaminergic system in the brain of the native Thai chicken, Gallus domesticus: localization and differential expression across the reproductive cycle. Gen Comp Endocrinol 2008, 159:107-115.

33. Laitinen JT: Dopamine stimulates $\mathrm{K}+$ efflux in the chick retina via D1 receptors independently of adenylyl cyclase activation. J Neurochem 1993, 61:1461-1469.

34. Demchyshyn LL, Sugamori KS, Lee FJ, Hamadanizadeh SA, Niznik HB: The dopamine D1D receptor. Cloning and characterization of three pharmacologically distinct D1-like receptors from Gallus domesticus. J Biol Chem 1995, 270:4005-4012.

35. Schnell SA, You S, El Halawani ME: D1 and D2 dopamine receptor messenger ribonucleic acid in brain and pituitary during the reproductive cycle of the turkey hen. Biol Reprod 1999, 60:1378-1383.

36. Chaiseha Y, Youngren O, Al-Zailaie K, El Halawani M: Expression of D1 and D2 dopamine receptors in the hypothalamus and pituitary during the turkey reproductive cycle: colocalization with vasoactive intestinal peptide. Neuroendocrinology 2003, 77:105-118.

37. Barrett JC, Fry B, Maller J, Daly MJ: Haploview: analysis and visualization of LD and haplotype maps. Bioinformatics 2005, 21:263-265.

38. Stephens M, Smith NJ, Donnelly P: A new statistical method for haplotype reconstruction from population data. Am J Hum Genet 2001, 68:978-989.

39. Livak KJ, Schmittgen TD: Analysis of relative gene expression data using real-time quantitative PCR and the 2(-Delta Delta C(T)) Method. Methods 2001, 25:402-408.

40. Soller M, Weigend S, Romanov MN, Dekkers JC, Lamont SJ: Strategies to assess structural variation in the chicken genome and its associations with biodiversity and biological performance. Poult Sci 2006, 85:2061-2078.

41. Wong GK, Liu B, Wang J, Zhang Y, Yang X, Zhang Z, Meng Q, Zhou J, Li D, Zhang J, Ni P, Li S, Ran L, Li H, Zhang J, Li R, Li S, Zheng H, Lin W, Li G, Wang X, Zhao W, Li J, Ye C, Dai M, Ruan J, Zhou Y, Li Y, He X, Zhang Y, Wang J, Huang $X$, Tong W, Chen J, Ye J, Chen C, Wei N, Li G, Dong L, Lan $F$, Sun $Y$, Zhang Z, Yang Z, Yu Y, Huang Y, He D, Xi Y, Wei D, Qi Q, Li W, Shi J, Wang $M$, Xie F, Wang J, Zhang X, Wang P, Zhao Y, Li N, Yang N, Dong W, Hu S, Zeng C, Zheng W, Hao B, Hillier LW, Yang SP, Warren WC, Wilson RK, Brandström M, Ellegren $H$, Crooijmans RP, Poel van der JJ, Bovenhuis H, Groenen MA, Ovcharenko I, Gordon L, Stubbs L, Lucas S, Glavina T, Aerts A, Kaiser P, Rothwell L, Young JR, Rogers S, Walker BA, van Hateren A, Kaufman J, Bumstead N, Lamont SJ, Zhou H, Hocking PM, Morrice D, de Koning DJ, Law A, Bartley N, Burt DW, Hunt H, Cheng HH, Gunnarsson U, Wahlberg P, Andersson L, Kindlund E, Tammi MT, Andersson B, Webber C, Ponting $C P$, Overton IM, Boardman PE, Tang $H_{\text {, }}$ Hubbard SJ, Wilson SA, Yu J, Wang J, Yang H, International Chicken Polymorphism Map Consortium: A genetic variation map for chicken with 2.8 million single-nucleotide polymorphisms. Nature 2004, 432:717-722.

42. Vallone D, Picetti R, Borrelli E: Structure and function of dopamine receptors. Neurosci Biobehav Rev 2000, 24:125-132.

43. Xu H, Gregory SG, Hauser ER, Stenger JE, Pericak-Vance MA, Vance JM, Züchner S, Hauser MA: SNPselector: a web tool for selecting SNPs for genetic association studies. Bioinformatics 2005, 21:4181-4186.

44. Minowa MT, Minowa T, Monsma FJ Jr, Sibley DR, Mouradian MM: Characterization of the $5^{\prime}$ flanking region of the human D1A dopamine receptor gene. Proc Natl Acad Sci USA 1992, 89:3045-3049.

45. Neidhardt J, Barthelmes D, Farahmand F, Fleischhauer JC, Berger W: Different amino acid substitutions at the same position in rhodopsin lead to distinct phenotypes. Invest Ophthalmol Vis Sci 2006, 47:1630-1635.
46. Schipani E, Kruse K, Jüppner H: A constitutively active mutant PTH-PTHrP receptor in Jansen-type metaphyseal chondrodysplasia. Science 1995, 268:98-100.

47. Xu HP, Shen X, Zhou M, Luo CL, Kang L, Liang Y, Zeng H, Zhang DX, Nie QH, Zhang XQ: The dopamine D2 receptor gene polymorphisms associated with chicken broodiness. Poult Sci 2010, 89:428-438.

48. Chaar ZY, Jackson A, Tiberi M: The cytoplasmic tail of the D1A receptor subtype: identification of specific domains controlling dopamine cellular responsiveness. Neurochem 2001, 79:1047-1058.

49. Jackson A, Iwasiow RM, Tiberi M: Distinct function of the cytoplasmic tail in human D1-like receptor ligand binding and coupling. FEBS Lett 2000, 470:183-188

50. Jensen AA, Pedersen UB, Kiemer A, Din N, Andersen PH: Functional importance of the carboxyl tail cysteine residues in the human D1 dopamine receptor. J Neurochem 1995, 65:1325-1331.

51. Tumova K, Iwasiow RM, Tiberi M: Insight into the mechanism of dopamine D1-like receptor activation. Evidence for a molecular interplay between the third extracellular loop and the cytoplasmic tail. J Biol Chem 2003, 278:8146-8153.

52. Tumova K, Zhang D, Tiberi M: Role of the fourth intracellular loop of D1like dopaminergic receptors in conferring subtype-specific signaling properties. FEBS Lett 2004, 576:461-467.

53. Probst WC, Snyder LA, Schuster DI, Brosius J, Sealfon SC: Sequence alignment of the G-protein coupled receptor superfamily. DNA Cell Biol 1992, 11:1-20.

54. Cho W, Taylor LP, Akil H: Mutagenesis of residues adjacent to transmembrane prolines alters D1 dopamine receptor binding and signal transduction. Mol Pharmacol 1996, 50:1338-1345.

55. Pollock NJ, Manelli AM, Hutchins CW, Steffey ME, MacKenzie RG, Frail DE: Serine mutations in transmembrane $V$ of the dopamine $D 1$ receptor affect ligand interactions and receptor activation. J Biol Chem 1992, 267:17780-17786.

56. Tomic M, Seeman P, George SR, O'Dowd BF: Dopamine D1 receptor mutagenesis: role of amino acids in agonist and antagonist binding. Biochem Biophys Res Commun 1993, 191:1020-1027.

57. Fremeau RT Jr, Duncan GE, Fornaretto MG, Dearry A, Gingrich JA, Breese GR, Caron MG: Localization of D1 dopamine receptor mRNA in brain supports a role in cognitive, affective, and neuroendocrine aspects of dopaminergic neurotransmission. Proc Natl Acad Sci USA 1991, 88:3772-3776.

58. Jackson DM, Westlind-Danielsson A: Dopamine receptors: molecular biology, biochemistry and behavioural aspects. Pharmacol Ther 1994, 64:291-370.

59. Monsma FJ Jr, Mahan LC, MCVittie LD, Gerfen CR, Sibley DR: Molecular cloning and expression of a D1 dopamine receptor linked to adenylyl cyclase activation. Proc Natl Acad Sci USA 1990, 87:6723-6727.

60. Niznik HB, Van Tol HH: Dopamine receptor genes: new tools for molecular psychiatry. J Psychiatry Neurosci 1992, 17:158-180.

61. Schnabel R, Metzger M, Jiang S, Hemmings HC Jr, Greengard P, Braun K: Localization of dopamine D1 receptors and dopaminoceptive neurons in the chick forebrain. J Comp Neurol 1997, 388:146-168.

doi:10.1186/1471-2156-11-17

Cite this article as: Xu et al:: The genetic effects of the dopamine D1 receptor gene on chicken egg production and broodiness traits. BMC Genetics 2010 11:17. 